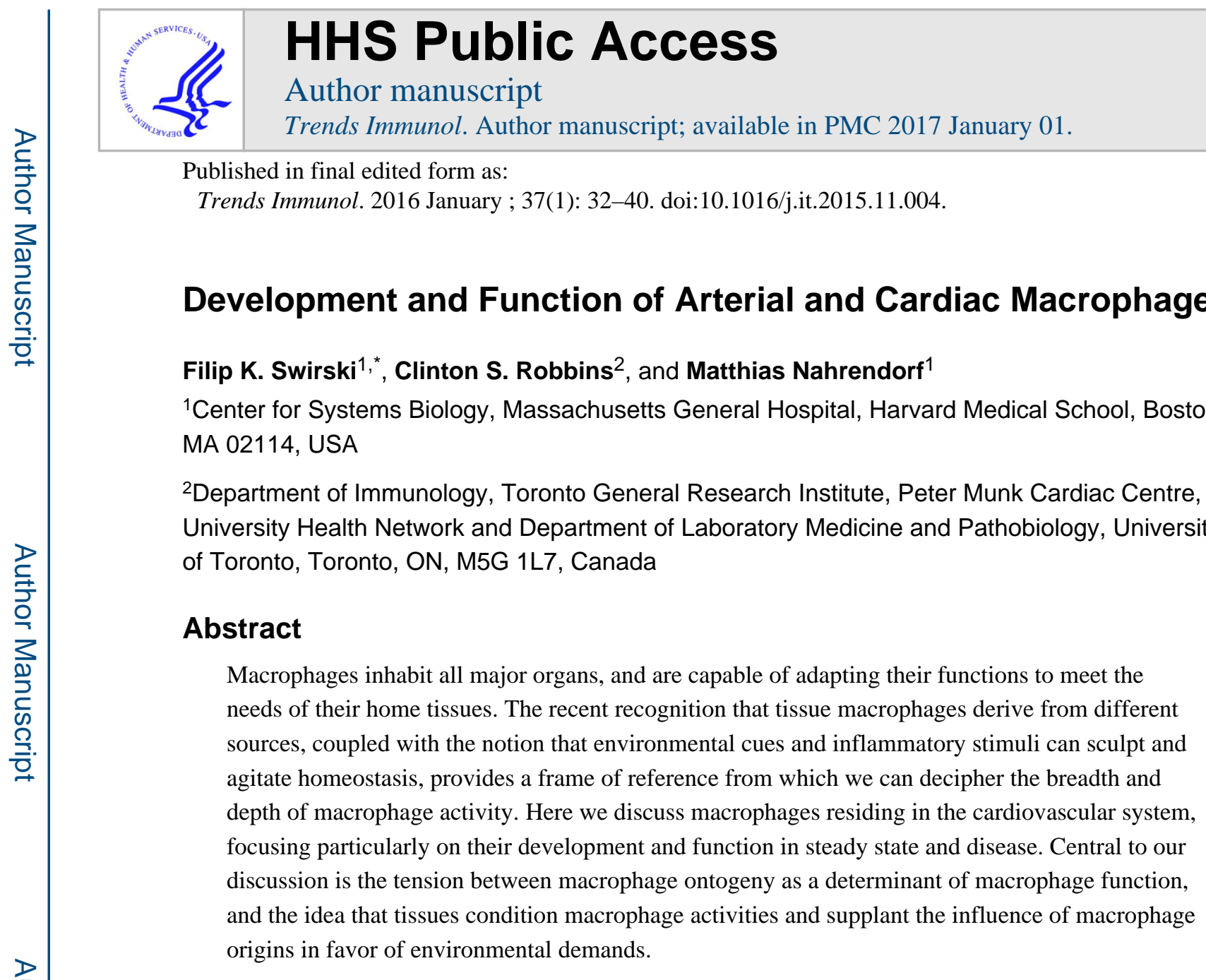

\title{
Introduction
}

The last decade has revolutionized our understanding of macrophage development by challenging a half century-old idea that tissue macrophages are primarily monocyte-derived. We now know that, in the steady state, macrophages in tissues such as the brain, liver, spleen, lung, peritoneum, gut, aorta, and heart have inhabited those tissues since embryogenesis with, in some cases, only minimal dependence on monocytes ${ }^{1,2}$. In response to infection or injury, however, monocytes infiltrate tissues in large numbers and give rise to macrophages that can be somewhat difficult to distinguish from their tissue-resident counterparts.

These insights, as significant as they are, also raise important questions. Does ontogeny dictate function? What are the functions of tissue-resident macrophages beyond those classically described? Are tissue-derived and monocyte-derived macrophages distinct, and if so how? Can tissue-derived macrophages proliferate throughout life, or do they rely on stillunknown progenitors? Here we consider these questions in the context of the current

*Correspondence: F.K.S. (fswirski@mgh.harvard.edu).

Publisher's Disclaimer: This is a PDF file of an unedited manuscript that has been accepted for publication. As a service to our customers we are providing this early version of the manuscript. The manuscript will undergo copyediting, typesetting, and review of the resulting proof before it is published in its final citable form. Please note that during the production process errors may be discovered which could affect the content, and all legal disclaimers that apply to the journal pertain. 
understanding of the ontogeny and function of macrophages residing in the heart and vessel walls, the two locations most dramatically affected by atherosclerosis and myocardial infarction. Because these diseases claim more lives than any others worldwide ${ }^{3}$ understanding macrophages' role therein may have broad clinical benefits.

\section{Tissue macrophages}

In 1984, van Furth and Diesselhoff-den reported on splenic macrophages' dual origins ${ }^{4}$. Through a series of experiments designed to profile proliferation and cell origin, the investigators concluded that approximately half of all splenic macrophages derive from monocyte influx while the remainder depend on local macrophage production through selfrenewal. At a time when macrophages were thought to be exclusively monocyte-derived, as formulated by van Furth and Cohn 16 years earlier ${ }^{5}$, the idea that macrophages self-renew without monocytes did not easily catch on; to this day, the 1968 paper has nearly 10 times more citations than its 1984 counterpoint. Over the years, numerous reports implicated local macrophage proliferation as a possible mechanism by which macrophages sustain themselves in the peritoneum ${ }^{6,7}$, lungs ${ }^{6,7}$, brain $^{8,9}, \operatorname{skin}^{10}$, and aorta ${ }^{11-16}$, yet these early findings' broader implications have only recently been explored. In many cases, the early studies relied on immunostaining strategies where cells co-expressing a myeloid or macrophage marker (i.e., CD68, F4/80) with a cell-cycle marker (Ki67, PCNA) were interpreted as evidence of proliferating macrophages. However, this strategy is problematic for lack of specificity and uncertainty as to magnitude of phenomenon. CD68, for example, is not specific to macrophages ${ }^{17}$ and a few cells expressing cell cycle markers - which signify that a cell is, or has been, in a particular stage of mitosis - tell us little about the importance of the process to the population as a whole. While surgical procedures such as parabiosis, where mice are joined together so as to share a common circulation, can inform on the influence of circulating cells to the replenishment of tissue-resident leukocytes, they do not address ontogeny.

If macrophages can either derive from monocytes or from local proliferation, does it follow that macrophages are ontogenically heterogeneous? Contemporary cell fate-mapping approaches show that macrophages seed the $\operatorname{skin}^{18}$ brain $^{19}$, and many other tissues ${ }^{20,21}$ during embryogenesis, before the emergence of monocytes. The studies typically rely on lineage tracing. One powerful strategy takes advantage of the fact that embryonic macrophages express the fractalkine receptor $\mathrm{Cx}_{3} \mathrm{cr} 1$, which can be used as a tag. Mice engineered with tamoxifen-inducible Cre recombinase under the direction of the $\mathrm{Cx}_{3} \mathrm{cr} 1$ promoter are bred with mice containing the ROSA26 locus, which has an inserted STOP codon flanked by loxP sequences upstream of a gene coding for a fluorochrome such as Enhanced Yellow Fluorescent Protein (EYFP) ${ }^{20}$. In the absence of any intervention, the STOP codon prevents fluorochrome expression. However, tamoxifen injected to pregnant mice drives the nuclear translocation of the Cre-ERT2 fusion protein in the pups' $\mathrm{Cx}_{3} \mathrm{cr} 1$ expressing cells (i.e., primitive macrophages). This leads to excision of the STOP codon by Cre recombinase, permanently marking all $\mathrm{Cx}_{3} \mathrm{cr}^{+}$cells and their progeny with EYFP. If tamoxifen is injected before the emergence of definitive hematopoiesis, monocytes remain EYFP- $^{-}$. The strategy, therefore, can distinguish cells that arise independently of hematopoietic stem cells from those that arise earlier in embryogenesis ${ }^{20}$. It is worthwhile 
mentioning, however, that the strategy, as powerful as it may be, is limited to cells expressing $\mathrm{Cx}_{3} \mathrm{cr} 1$ and can confound results if the Cre-ERT2 fusion protein is either leaky or weakly translocated after tamoxifen injection. Thus, this particular strategy precludes conclusions regarding potential $\mathrm{Cx}_{3} \mathrm{Cr}^{-}$progenitors that may be vital to macrophage biology, and indeed, alternative lineage tracing approaches have led to some conflicting results on the nature of macrophage development ${ }^{22}$.

That said, by using the $\mathrm{Cx}_{3} \mathrm{cr} 1$ system we have learned that the yolk sac (YS) is the first source of macrophages during development and thus constitutes the first macrophage colonization wave, which occurs around embryonic day $8.5(\mathrm{E} 8.5)^{23,24}$. A second wave occurs when fetal liver monocytes, which ultimately derive from YS-derived erythromyeloid progenitors (EMP) ${ }^{25}$, and which are produced at E13.5, settle most organs and replace the first wave of YS-derived macrophages ${ }^{26}$. At birth, when hematopoiesis shifts to the bone marrow, macrophage colonization is complete in some locations but incomplete in others. The brain requires no further monocyte input, while in the intestine, monocytes continuously replace resident macrophages ${ }^{27}$. Thus in most organs, with the exception of the brain, at least three macrophage colonization waves occur: YS-derived macrophages appear in the first wave; fetal liver monocytes colonize organs and differentiate to macrophages in the second wave; and post-natal bone marrow-derived monocytes colonize in the third wave. We do not yet know whether this third wave persists or diminishes throughout life, and some have challenged the idea that hematopoietic stem cell-independent macrophages are relevant anywhere but the brain ${ }^{22}$. Nevertheless, there is a growing consensus that individual organs rely on these successive macrophage waves differently, as illustrated by the two extremes of the brain, which relies predominantly on embryonic seeding, and the gut, which accumulates monocyte-derived macrophages in the adult. For more details on the various macrophage progenitor precursors and the relative timing by which these cells contribute to resident macrophages we refer the reader to recent reviews ${ }^{1,28}$.

\section{Cardiac and Arterial Macrophage Ontogeny and Function in Homeostasis}

The mouse heart contains an abundant macrophage population ${ }^{29}$ (Figure 1). Visualizing cardiac macrophages is possible in $\mathrm{Cx}_{3} \mathrm{Crl}^{g f p /+}$ mice because the cells express the fractalkine receptor $\mathrm{Cx}_{3} \mathrm{cr} 1$, a feature they share with some tissue-resident macrophages ${ }^{30}$. Recent interest in resident macrophage ontogeny and function has produced three studies, published independently and in short succession, on the cells' role in the heart. Collectively, the studies do not yet present a cohesive narrative. Two groups used techniques such as genetic fate mapping, similar to those described above, and parabiosis to conclude that at steady state most cardiac macrophages in the adult self-renew and do not rely on monocytes for replenishment ${ }^{31,32}$. Consequently, cardiac macrophages are ontogenically more like brain macrophages than intestinal macrophages. The third group employed similar approaches but reached the somewhat dissenting conclusion that bone marrow-derived monocytes progressively replace fetally-sourced cells throughout life ${ }^{33}$, which would align cardiac macrophage ontogeny with intestinal macrophages. Additional studies are needed to sway the weight of evidence one way or the other. If post-natal colonization indeed persists into old age, it will be important to determine if such colonization contributes meaningfully to 
the cardiac macrophage pool. If it does, it remains to be seen whether such a contribution is functionally distinct and relevant.

The large arteries are also densely populated by macrophages residing predominantly in the vessel wall's outer adventitial layer, yet their ontogeny and maintenance mechanisms have remained elusive, likely because cell isolation in the aorta is not trivial. A recent study, however, has met this challenge. Using multiple fate mapping approaches, the study has shown that arterial macrophages develop embryonically from early and late EMP generated in the $\mathrm{YS}^{34}$. Arterial macrophage colonization associates with a brief period of blood monocyte recruitment immediately after birth. The arterial macrophage pool may have unique development because, unlike macrophages in the intestine ${ }^{27}$, arterial macrophages receive no further meaningful contribution from blood monocytes in the steady state once the post-natal wave subsides. In adults, arterial macrophages are maintained by local proliferation that sustains their numbers not only in the steady state but also during rebound after depletion following sepsis ${ }^{34}$. Like cardiac macrophages, arterial macrophages retain $\mathrm{Cx}_{3} \mathrm{cr} 1$ expression, which promotes arterial macrophage survival similar to that reported for Ly- $6 \mathrm{C}^{\text {low }}$ monocytes and macrophages residing in the brain, kidney, and solid tumors.

Moreover, the arteries contain $\mathrm{CD}_{3} 1^{+}$cells and PDGFRa ${ }^{+}$mesenchymal cells that produce $\mathrm{CX}_{3} \mathrm{CL} 1$ locally, possibly constituting a maintenance niche ${ }^{34}$.

The word "macrophage" derives from the greek makros (large) and phagein (eater) - true to their name, macrophages are highly phagocytic, as discovered by Elie Metchnikoff in 1882. Because macrophages arise from different sources and occupy such divergent tissues, do they participate in tissue-specific processes other than phagocytosis? At the molecular level, macrophages from various tissues differ from each other, though they share a transcriptional signature that distinguishes them from other leukocytes ${ }^{35}$. As evaluated by profiling either the dynamics of four histone modifications across seven tissue-resident macrophage populations ${ }^{36}$ or by analyzing the transcriptomes and enhancer landscapes of peritoneal macrophages and microglia ${ }^{37}$, two independent groups have recently shown that macrophage diversity relies on tissue-specific enhancers. This tissue-specificity is partially reversible. For example, peritoneal macrophages acquire most, if not all, features of lung macrophages upon adoptive transfer to the lung 36 .

Perhaps as a consequence of this tissue-specific control of macrophage identity, different tissues impart macrophages with specialized functions. Peritoneal macrophages control migration of IgA-producing B cells to the gut ${ }^{38}$ while red pulp macrophages in the spleen ingest senescent erythrocytes and recycle iron ${ }^{39}$. Microglia prune neurons ${ }^{40}$, lung macrophages clear surfactant ${ }^{41}$, and adipose tissue macrophages participate in thermoregulation $^{42,43}$. In hematopoietic sites, macrophages are integral components of the stem cell niche 44,45 , and in the interstitium their osmosensitive properties control responses to sodium content ${ }^{46,47}$. Although some of these activities are clearly connected to phagocytosis, others point to processes that are independent of ingestion.

What might cardiac and arterial macrophages do in the steady state? In the adult heart, macrophages can ingest bacteria and apoptotic cells $31,32,48,49$, and though the heart is rarely under threat of bacterial infection, phagocytosis of aged or dying cardiomyocytes is 
plausible. In the neonatal heart, cardiac macrophages are essential to cardiac regeneration following injury, presumably because they promote angiogenesis ${ }^{50}$. This protective mechanism disappears within two weeks of life, around the time that monocyte-derived macrophages populate the heart ${ }^{51}$. One interpretation of these findings is that embryonic macrophages are inherently reparative while monocyte-derived macrophages are inherently inflammatory. By changing the relative composition of ontogenically-distinct cardiac macrophages, the argument goes, the heart's capacity to respond to injury or infection changes at the expense of its ability to regenerate. However, the heart environment, which might shape the macrophage response without regard to ontogeny, changes dramatically during those first few weeks of life as cardiomyocytes experience tremendous proliferative bursts $^{52}$. Moreover, the inflammatory component in neonatal hearts is functional, and indeed very effective even before bone marrow-dependent colonization. Thus, the relative contribution of the local environment to macrophage ontogeny and function in the steady state requires further elaboration.

The homeostatic contribution of arterial macrophages is unknown, but it is probable that phagocytosis plays a decisive role, if only because arterial macrophages are phagocytic ${ }^{34}$. A growing literature also suggests that arterial macrophages are crucial mediators of hypertension ${ }^{53-56}$. One recent study utilizing angiotensin II infusion to induce hypertension concluded that vessel wall-infiltrating bone marrow-derived inflammatory monocytes are the central culprits responsible for blood pressure dysregulation ${ }^{56}$. This is, however, a pathogenic process. It remains to be determined if adventitial macrophages, as arguably the most numerous leukocytic occupants of the aorta in the steady state, control vascular tone.

\section{Altered macrophage ontogeny and function in the inflamed cardiovascular system}

If the origin and role of cardiac and vascular macrophages in the steady state are unclear, we can rely on a much larger body of work describing how these cells participate in disease ${ }^{57,58}$. Building on macrophages' known roles in immunity and inflammation, along with trailblazing studies on how the heart behaves after ischemic injury ${ }^{59}$, the first contemporary studies linking macrophages with the heart were performed in the context of myocardial infarction and utilized flow cytometry of single cell suspensions from enzymatically digested cardiac tissue ${ }^{60}$. In response to ischemia, which occurs when coronary arteries that supply oxygenated blood to the heart are blocked, the myocardium recruits large numbers of leukocytes. Shortly after a sharp neutrophil peak, circulating inflammatory Ly-6 $\mathrm{C}^{\text {high }}$ monocytes, guided by the chemokine-chemokine receptor pair CCL2-CCR2, infiltrate and contribute to inflammation by producing cytokines, proteases, and oxidative stress-promoting enzymes ${ }^{61}$. Within 5 days, in the absence of persistent inflammatory stimuli, the recruited monocytes differentiate to reparative Ly-6C $\mathrm{C}^{\text {low }}$ macrophages that limit inflammation and contribute to scar formation ${ }^{62,63}$. The reparative monocyte-derived macrophages ${ }^{62}$, which probably reside alongside reparative tissue-derived embryonic macrophages ${ }^{51}$, proliferate locally, persist for weeks, and promote efferocytosis, cardiac myocyte survival, angiogenesis, and fibrosis ${ }^{2,48,64-66}$. While the massive recruitment of circulating inflammatory monocytes that differentiate to reparative proliferating 
macrophages has been demonstrated with fate mapping approaches, there is still a substantial gap in our understanding of what happens later, when inflammation resolves. For example, we do not know whether, within months after myocardial infarction, macrophages residing in the heart are monocyte or tissue-derived. On the one hand, it is possible that myocardial infarction transforms the macrophage repertoire ${ }^{51}$ whereby monocyte-derived macrophages permanently replace embryonically-derived macrophages. On the other hand, embryonically-derived macrophages might eventually return by outcompeting their monocyte-derived counterparts either by more pronounced self-renewal or by as-yetunknown replenishment by local progenitors. Answering this question will rely on the aforementioned lineage tracing approaches but, to be meaningful, will also require functional analyses. The essential question is whether ontogeny dictates function. Macrophages might simply adapt to their local environment and acquire behaviors that supplant any pertinent traces of ontogeny. To be sure, macrophages might be trained to "remember" the past injury, akin to how monocytes remember a previous infection ${ }^{67-69}$, but the training need not depend on how macrophages arose in the first place.

In atherosclerosis, the lipid-driven inflammatory disease that leads to myocardial infarction and stroke, monocytes traverse the endothelium and accumulate progressively in the vessel wall. Upon arrival in the intima, monocytes presumably ingest excess lipoproteins that have accumulated independently of leukocyte help. Monocytes can differentiate to macrophages, but it is unclear whether monocyte-to-macrophage differentiation precedes lipoprotein ingestion, accompanies it, or is driven by it. Regardless of the sequence, monocytes that become macrophages help grow and exacerbate atherosclerotic lesions by performing many important actions, as authoritatively reviewed elsewhere ${ }^{70-74}$. The numerical escalation of arterial macrophages relies on a combination of monocyte recruitment ${ }^{75,76}$, local macrophage proliferation ${ }^{77}$, macrophage death ${ }^{78}$, and exit ${ }^{79}$. Studies using parabiotic mice have shown that nascent lesions rely predominantly on monocyte recruitment. Established lesions, in contrast, are sustained by local macrophage proliferation, and though monocytes continue to infiltrate the lesion, macrophage self renewal becomes a major mechanism by which lesions grow ${ }^{77}$. Among other things, these data show that macrophage proliferation is not restricted to monocyte-independent macrophages, such as those residing in the peritoneum or skin ${ }^{18,80}$. While adventitial macrophages, which derive from post-birth colonization $^{34}$, and thus differ from adult monocyte-derived macrophages that accumulate in disease, continue to proliferate during atherosclerosis, their rate of proliferation remains relatively unchanged from the steady state ${ }^{77}$. The importance of adventitial vs. intimal macrophages to the development and exacerbation of atherosclerosis requires further study.

Since local proliferation is a major mechanism that sustains macrophages in lesions ${ }^{77}$ and monocyte infiltration is continuous even in established atherosclerosis ${ }^{75,77,81}$, do monocytes participate in ways that transcend or sidestep differentiation to macrophages? It is indeed possible that monocyte-to-macrophage differentiation in established lesions is a relatively minor event. After all, monocytes can readily traverse through tissue without becoming macrophages ${ }^{82,83}$, perhaps migrating back and forth across the endothelium, as has been described for neutrophils ${ }^{84,85}$. Can monocytes cross the endothelial layer but never differentiate to lesional macrophages? If such a process occurs, is it important? Answering 
these questions would determine whether monocytes are "simply" macrophage precursors or have palpably macrophage-independent functions in atherosclerosis.

In both myocardial infarction and atherosclerosis, monocyte-derived macrophages are phagocytic, potentially present antigens, contribute to scar formation, and either augment or attenuate the inflammatory cascade. Within days after myocardial infarction, when inflammatory stimuli wane, macrophages functionally shift from promoting inflammation to supporting repair. In atherosclerosis, chronic hypercholesterolemia fuels non-resolving inflammation and presumably keeps macrophages locked in an inflammatory state. By scavenging dead cells, and by producing either IL- $1 \beta$ and TNFa or TGF $\beta$ and IL-10, macrophages in the myocardium and the vessel wall perform classic macrophage functions that correspond to inflammation, wound repair, and fibrosis ${ }^{86}$. If ontogeny is inconsequential, then in the absence of persistent inflammatory stimuli monocyte-derived cells should integrate into the resident pool and pursue homeostatic roles specific to the environments they inhabit. If ontogeny dictates function, however, monocyte-derived macrophages will either disappear or retain their developmental signature.

\section{Concluding Remarks}

Like the brain, lung, spleen, peritoneum, gut, or kidney, the heart and vessel wall contain macrophages whose initial accumulation occurs early in development. Macrophages are not tissue visitors but essential components of organ systems. Having deciphered macrophage ontogeny's broad strokes, we face a watershed moment in macrophage biology. Does ontogeny determine behavior? In answering this question, we can consider three possibilities:

i. Macrophage ontogeny dictates function. Since macrophages originate from different locations, it is possible that differentially-sourced macrophages pursue different functions. In response to ischemic injury or during development of atherosclerosis, for example, infiltrating monocytes become macrophages that are decidedly inflammatory and thus may differ from the resident pool. Moreover, in the absence of inflammation, resident macrophages can be distinguished from each other by differential expression of functionally relevant surface markers such as MHCII. In aggregate, it is fair to postulate that macrophage heterogeneity is driven by macrophage ontogeny. If so, then we should think about macrophage ontogenic groups and target distinct macrophage lineages for the purposes of therapy ${ }^{51}$.

ii. The tissue dictates macrophage function. In this scenario, it is the tissue that programs macrophage function irrespective of origins. Infiltrating monocytes indeed contribute to inflammation but that contribution might simply be numerical rather than functionally unique; resident embryonically-derived macrophages, though less numerous, may also secrete inflammatory cytokines and proteases in those first few days after an inflammatory insult. Moreover, even though resident macrophages express different cell surface markers, many such markers fluctuate in expression intensity and do not necessarily reflect origins. For instance, monocytederived macrophages may express CCR2 shortly after recruitment but attenuate this marker later. We already have compelling evidence that the tissue determines 
macrophage identity and educates arriving monocytes $36,37,87$. If this scenario is correct, then therapeutic strategies should either target recruitment to reduce macrophage burden or converge on the macrophage population as a whole without attending to otherwise functionally irrelevant origins.

iii. The nature vs. nurture argument is a false dichotomy because control by ontogeny vs control by tissue environment are not mutually exclusive. It is possible that origins matter even if they do not regulate the sequence by which macrophages participate in inflammation and repair. For example, origins might dictate cell survival. In this scenario, one can envision infiltrating monocytes as an on-demand buffer system that can be mobilized in times of crisis to promote a swift and efficient response. Upon infiltration, monocytes and tissue resident macrophages may be programmed by the tissue to integrate functionally and pursue the same tasks. As demand for an increased population diminishes, the monocyte-derived cells might be outcompeted by the resident pool either because resident macrophages have an inherently more robust capacity to replicate or because they rely on tissue-resident precursors. In this scenario, ontogeny is imperative to cell survival, but the tissue is also critical because it configures cell function.

The next several years are bound to be exciting as we untangle the fundamentals and associated nuances of macrophage development and function. We already know that macrophages are highly modifiable cells that reside almost everywhere in the body and contribute to its key processes. Moving on, we will almost certainly be confronted by surprises that will inspire yet another refinement in our understanding of how these cells shape and are shaped by the systems they inhabit.

\section{Acknowledgments}

This work was supported by grants R01HL117829, R01NS084863, MGH Research Scholar Award (to M.N.), and R01HL095612, R01HL128264, and Howard M. Goodman Fellowship (to F.K.S.). C.S.R.

(clint.robbins@utoronto.ca) and M.N. (mnahrendorf@mgh.harvard.edu) can also be contacted to discuss this article.

\section{References}

1. Sieweke MH, Allen JE. Beyond stem cells: self-renewal of differentiated macrophages. Science. 2013; 342:1242974. [PubMed: 24264994]

2. Epelman S, Lavine KJ, Randolph GJ. Origin and functions of tissue macrophages. Immunity. 2014; 41:21-35. [PubMed: 25035951]

3. Bloom, DE.; Cafiero, ET.; Jane-Llopis, E.; Abrahams-Gessel, S.; Bloom, LR.; Fathima, S.; Feigl, AB.; Gaziano, T.; Mowafi, M.; Pandya, A., et al. The Global Economic Burden of Noncommunicable Diseases. Geneva: World Economic Forum; 2011.

4. van Furth R, Diesselhoff-den Dulk MM. Dual origin of mouse spleen macrophages. J Exp Med. 1984; 160:1273-1283. [PubMed: 6491600]

5. van Furth R, Cohn ZA. The origin and kinetics of mononuclear phagocytes. J Exp Med. 1968; 128:415-435. [PubMed: 5666958]

6. Sawyer RT, Strausbauch PH, Volkman A. Resident macrophage proliferation in mice depleted of blood monocytes by strontium-89. Lab Invest. 1982; 46:165-170. [PubMed: 6174824]

7. Tarling JD, Lin HS, Hsu S. Self-renewal of pulmonary alveolar macrophages: evidence from radiation chimera studies. J Leukoc Biol. 1987; 42:443-446. [PubMed: 3316460] 
8. Lawson LJ, Perry VH, Gordon S. Turnover of resident microglia in the normal adult mouse brain. Neuroscience. 1992; 48:405-415. [PubMed: 1603325]

9. de Groot CJ, Huppes W, Sminia T, Kraal G, Dijkstra CD. Determination of the origin and nature of brain macrophages and microglial cells in mouse central nervous system, using non-radioactive in situ hybridization and immunoperoxidase techniques. Glia. 1992; 6:301-309. [PubMed: 1281462]

10. Merad M, Manz MG, Karsunky H, Wagers A, Peters W, Charo I, Weissman IL, Cyster JG, Engleman EG. Langerhans cells renew in the skin throughout life under steady-state conditions. Nat Immunol. 2002; 3:1135-1141. [PubMed: 12415265]

11. Gordon D, Reidy MA, Benditt EP, Schwartz SM. Cell proliferation in human coronary arteries. Proc Natl Acad Sci U S A. 1990; 87:4600-4604. [PubMed: 1972277]

12. Rosenfeld ME, Ross R. Macrophage and smooth muscle cell proliferation in atherosclerotic lesions of WHHL and comparably hypercholesterolemic fat-fed rabbits. Arteriosclerosis. 1990; 10:680 687. [PubMed: 2403295]

13. Pickering JG, Weir L, Jekanowski J, Kearney MA, Isner JM. Proliferative activity in peripheral and coronary atherosclerotic plaque among patients undergoing percutaneous revascularization. $\mathrm{J}$ Clin Invest. 1993; 91:1469-1480. [PubMed: 8097207]

14. Rekhter MD, Gordon D. Active proliferation of different cell types, including lymphocytes, in human atherosclerotic plaques. Am J Pathol. 1995; 147:668-677. [PubMed: 7677178]

15. Lutgens E, Daemen M, Kockx M, Doevendans P, Hofker M, Havekes L, Wellens H, de Muinck ED. Atherosclerosis in APOE*3-Leiden transgenic mice: from proliferative to atheromatous stage. Circulation. 1999; 99:276-283. [PubMed: 9892595]

16. Lutgens E, de Muinck ED, Kitslaar PJ, Tordoir JH, Wellens HJ, Daemen MJ. Biphasic pattern of cell turnover characterizes the progression from fatty streaks to ruptured human atherosclerotic plaques. Cardiovasc Res. 1999; 41:473-479. [PubMed: 10341847]

17. Iqbal AJ, McNeill E, Kapellos TS, Regan-Komito D, Norman S, Burd S, Smart N, Machemer DE, Stylianou E, McShane H, et al. Human CD68 promoter GFP transgenic mice allow analysis of monocyte to macrophage differentiation in vivo. Blood. 2014; 124:e33-44. [PubMed: 25030063]

18. Chorro L, Sarde A, Li M, Woollard KJ, Chambon P, Malissen B, Kissenpfennig A, Barbaroux JB, Groves R, Geissmann F. Langerhans cell (LC) proliferation mediates neonatal development, homeostasis, and inflammation-associated expansion of the epidermal LC network. J Exp Med. 2009; 206:3089-3100. [PubMed: 19995948]

19. Ginhoux F, Greter M, Leboeuf M, Nandi S, See P, Gokhan S, Mehler MF, Conway SJ, Ng LG, Stanley ER, et al. Fate mapping analysis reveals that adult microglia derive from primitive macrophages. Science. 2010; 330:841-845. [PubMed: 20966214]

20. Yona S, Kim KW, Wolf Y, Mildner A, Varol D, Breker M, Strauss-Ayali D, Viukov S, Guilliams M, Misharin A, et al. Fate mapping reveals origins and dynamics of monocytes and tissue macrophages under homeostasis. Immunity. 2013; 38:79-91. [PubMed: 23273845]

21. Hashimoto D, Chow A, Noizat C, Teo P, Beasley MB, Leboeuf M, Becker CD, See P, Price J, Lucas D, et al. Tissue-resident macrophages self-maintain locally throughout adult life with minimal contribution from circulating monocytes. Immunity. 2013; 38:792-804. [PubMed: 23601688]

22. Sheng J, Ruedl C, Karjalainen K. Most Tissue-Resident Macrophages Except Microglia Are Derived from Fetal Hematopoietic Stem Cells. Immunity. 2015; 43:382-393. [PubMed: 26287683]

23. Schulz C, Gomez Perdiguero E, Chorro L, Szabo-Rogers H, Cagnard N, Kierdorf K, Prinz M, Wu B, Jacobsen SE, Pollard JW, et al. A lineage of myeloid cells independent of Myb and hematopoietic stem cells. Science. 2012; 336:86-90. [PubMed: 22442384]

24. Gomez Perdiguero E, Klapproth K, Schulz C, Busch K, Azzoni E, Crozet L, Garner H, Trouillet C, de Bruijn MF, Geissmann F, et al. Tissue-resident macrophages originate from yolk-sac-derived erythro-myeloid progenitors. Nature. 2015; 518:547-551. [PubMed: 25470051]

25. Hoeffel G, Wang Y, Greter M, See P, Teo P, Malleret B, Leboeuf M, Low D, Oller G, Almeida F, et al. Adult Langerhans cells derive predominantly from embryonic fetal liver monocytes with a minor contribution of yolk sac-derived macrophages. J Exp Med. 2012; 209:1167-1181. [PubMed: 22565823] 
26. Hoeffel G, Chen J, Lavin Y, Low D, Almeida FF, See P, Beaudin AE, Lum J, Low I, Forsberg EC, et al. C-Myb(+) erythro-myeloid progenitor-derived fetal monocytes give rise to adult tissueresident macrophages. Immunity. 2015; 42:665-678. [PubMed: 25902481]

27. Bain CC, Bravo-Blas A, Scott CL, Gomez Perdiguero E, Geissmann F, Henri S, Malissen B, Osborne LC, Artis D, Mowat AM. Constant replenishment from circulating monocytes maintains the macrophage pool in the intestine of adult mice. Nat Immunol. 2014; 15:929-937. [PubMed: 25151491]

28. Ginhoux F, Jung S. Monocytes and macrophages: developmental pathways and tissue homeostasis. Nat Rev Immunol. 2014; 14:392-404. [PubMed: 24854589]

29. Nahrendorf M, Swirski FK. Monocyte and macrophage heterogeneity in the heart. Circ Res. 2013; 112:1624-1633. [PubMed: 23743228]

30. Pinto AR, Paolicelli R, Salimova E, Gospocic J, Slonimsky E, Bilbao-Cortes D, Godwin JW, Rosenthal NA. An abundant tissue macrophage population in the adult murine heart with a distinct alternatively-activated macrophage profile. PLoS One. 2012; 7:e36814. [PubMed: 22590615]

31. Epelman S, Lavine KJ, Beaudin AE, Sojka DK, Carrero JA, Calderon B, Brija T, Gautier EL, Ivanov S, Satpathy AT, et al. Embryonic and adult-derived resident cardiac macrophages are maintained through distinct mechanisms at steady state and during inflammation. Immunity. 2014; 40:91-104. [PubMed: 24439267]

32. Heidt T, Courties G, Dutta P, Sager HB, Sebas M, Iwamoto Y, Sun Y, Da Silva N, Panizzi P, van der Laan AM, et al. Differential contribution of monocytes to heart macrophages in steady-state and after myocardial infarction. Circ Res. 2014; 115:284-295. [PubMed: 24786973]

33. Molawi K, Wolf Y, Kandalla PK, Favret J, Hagemeyer N, Frenzel K, Pinto AR, Klapproth K, Henri S, Malissen B, et al. Progressive replacement of embryo-derived cardiac macrophages with age. J Exp Med. 2014; 211:2151-2158. [PubMed: 25245760]

34. Ensan S, Li A, Besla R, Degousee N, Cosme J, Roufaiel M, Shikatani EA, El-Maklizi M, Williams JW, Robins L, et al. Self-renewing resident arterial macrophages arise from embryonic Cx $3 \mathrm{cr} 1+$ precursors and circulating monocytes immediately after birth. Nat Immunol. 2015

35. Gautier EL, Shay T, Miller J, Greter M, Jakubzick C, Ivanov S, Helft J, Chow A, Elpek KG, Gordonov $\mathrm{S}$, et al. Gene-expression profiles and transcriptional regulatory pathways that underlie the identity and diversity of mouse tissue macrophages. Nat Immunol. 2012; 13:1118-1128. [PubMed: 23023392]

36. Lavin Y, Winter D, Blecher-Gonen R, David E, Keren-Shaul H, Merad M, Jung S, Amit I. Tissueresident macrophage enhancer landscapes are shaped by the local microenvironment. Cell. 2014; 159:1312-1326. [PubMed: 25480296]

37. Gosselin D, Link VM, Romanoski CE, Fonseca GJ, Eichenfield DZ, Spann NJ, Stender JD, Chun HB, Garner H, Geissmann F, et al. Environment drives selection and function of enhancers controlling tissue-specific macrophage identities. Cell. 2014; 159:1327-1340. [PubMed: 25480297]

38. Okabe Y, Medzhitov R. Tissue-specific signals control reversible program of localization and functional polarization of macrophages. Cell. 2014; 157:832-844. [PubMed: 24792964]

39. Kohyama M, Ise W, Edelson BT, Wilker PR, Hildner K, Mejia C, Frazier WA, Murphy TL, Murphy KM. Role for Spi-C in the development of red pulp macrophages and splenic iron homeostasis. Nature. 2009; 457:318-321. [PubMed: 19037245]

40. Paolicelli RC, Bolasco G, Pagani F, Maggi L, Scianni M, Panzanelli P, Giustetto M, Ferreira TA, Guiducci E, Dumas L, et al. Synaptic pruning by microglia is necessary for normal brain development. Science. 2011; 333:1456-1458. [PubMed: 21778362]

41. Suzuki T, Arumugam P, Sakagami T, Lachmann N, Chalk C, Sallese A, Abe S, Trapnell C, Carey B, Moritz T, et al. Pulmonary macrophage transplantation therapy. Nature. 2014; 514:450-454. [PubMed: 25274301]

42. Nguyen KD, Qiu Y, Cui X, Goh YP, Mwangi J, David T, Mukundan L, Brombacher F, Locksley RM, Chawla A. Alternatively activated macrophages produce catecholamines to sustain adaptive thermogenesis. Nature. 2011; 480:104-108. [PubMed: 22101429] 
43. Qiu Y, Nguyen KD, Odegaard JI, Cui X, Tian X, Locksley RM, Palmiter RD, Chawla A. Eosinophils and type 2 cytokine signaling in macrophages orchestrate development of functional beige fat. Cell. 2014; 157:1292-1308. [PubMed: 24906148]

44. Chow A, Huggins M, Ahmed J, Hashimoto D, Lucas D, Kunisaki Y, Pinho S, Leboeuf M, Noizat C, van Rooijen N, et al. CD169(+) macrophages provide a niche promoting erythropoiesis under homeostasis and stress. Nat Med. 2013; 19:429-436. [PubMed: 23502962]

45. Dutta P, Hoyer FF, Grigoryeva LS, Sager HB, Leuschner F, Courties G, Borodovsky A, Novobrantseva T, Ruda VM, Fitzgerald K, et al. Macrophages retain hematopoietic stem cells in the spleen via VCAM-1. J Exp Med. 2015; 212:497-512. [PubMed: 25800955]

46. Machnik A, Neuhofer W, Jantsch J, Dahlmann A, Tammela T, Machura K, Park JK, Beck FX, Muller DN, Derer W, et al. Macrophages regulate salt-dependent volume and blood pressure by a vascular endothelial growth factor-C-dependent buffering mechanism. Nat Med. 2009; 15:545552. [PubMed: 19412173]

47. Wiig H, Schroder A, Neuhofer W, Jantsch J, Kopp C, Karlsen TV, Boschmann M, Goss J, Bry M, Rakova N, et al. Immune cells control skin lymphatic electrolyte homeostasis and blood pressure. J Clin Invest. 2013; 123:2803-2815. [PubMed: 23722907]

48. Wan E, Yeap XY, Dehn S, Terry R, Novak M, Zhang S, Iwata S, Han X, Homma S, Drosatos K, et al. Enhanced efferocytosis of apoptotic cardiomyocytes through myeloid-epithelial-reproductive tyrosine kinase links acute inflammation resolution to cardiac repair after infarction. Circ Res. 2013; 113:1004-1012. [PubMed: 23836795]

49. Pinto AR, Godwin JW, Rosenthal NA. Macrophages in cardiac homeostasis, injury responses and progenitor cell mobilisation. Stem Cell Res. 2014; 13:705-714. [PubMed: 25087895]

50. Aurora AB, Porrello ER, Tan W, Mahmoud AI, Hill JA, Bassel-Duby R, Sadek HA, Olson EN. Macrophages are required for neonatal heart regeneration. J Clin Invest. 2014; 124:1382-1392. [PubMed: 24569380]

51. Lavine KJ, Epelman S, Uchida K, Weber KJ, Nichols CG, Schilling JD, Ornitz DM, Randolph GJ, Mann DL. Distinct macrophage lineages contribute to disparate patterns of cardiac recovery and remodeling in the neonatal and adult heart. Proc Natl Acad Sci U S A. 2014; 111:16029-16034. [PubMed: 25349429]

52. Naqvi N, Li M, Calvert JW, Tejada T, Lambert JP, Wu J, Kesteven SH, Holman SR, Matsuda T, Lovelock JD, et al. A proliferative burst during preadolescence establishes the final cardiomyocyte number. Cell. 2014; 157:795-807. [PubMed: 24813607]

53. Shah KH, Shi P, Giani JF, Janjulia T, Bernstein EA, Li Y, Zhao T, Harrison DG, Bernstein KE, Shen XZ. Myeloid Suppressor Cells Accumulate and Regulate Blood Pressure in Hypertension. Circ Res. 2015; 117:858-869. [PubMed: 26294657]

54. Shirai T, Hilhorst M, Harrison DG, Goronzy JJ, Weyand CM. Macrophages in vascular inflammation--From atherosclerosis to vasculitis. Autoimmunity. 2015; 48:139-151. [PubMed: 25811915]

55. Wenzel U, Turner JE, Krebs C, Kurts C, Harrison DG, Ehmke H. Immune Mechanisms in Arterial Hypertension. J Am Soc Nephrol. 2015

56. Moore JP, Vinh A, Tuck KL, Sakkal S, Krishnan SM, Chan CT, Lieu M, Samuel CS, Diep H, Kemp-Harper BK, et al. M2 macrophage accumulation in the aortic wall during angiotensin II infusion in mice is associated with fibrosis, elastin loss, and elevated blood pressure. Am J Physiol Heart Circ Physiol. 2015; 309:H906-17. [PubMed: 26071547]

57. Swirski FK, Nahrendorf M. Leukocyte behavior in atherosclerosis, myocardial infarction, and heart failure. Science. 2013; 339:161-166. [PubMed: 23307733]

58. Nahrendorf M, Pittet MJ, Swirski FK. Monocytes: protagonists of infarct inflammation and repair after myocardial infarction. Circulation. 2010; 121:2437-2445. [PubMed: 20530020]

59. Frangogiannis NG. Chemokines in the ischemic myocardium: from inflammation to fibrosis. Inflamm Res. 2004; 53:585-595. [PubMed: 15693606]

60. Nahrendorf M, Swirski FK, Aikawa E, Stangenberg L, Wurdinger T, Figueiredo JL, Libby P, Weissleder R, Pittet MJ. The healing myocardium sequentially mobilizes two monocyte subsets with divergent and complementary functions. J Exp Med. 2007; 204:3037-3047. [PubMed: 18025128] 
61. Dewald O, Zymek P, Winkelmann K, Koerting A, Ren G, Abou-Khamis T, Michael LH, Rollins BJ, Entman ML, Frangogiannis NG. CCL2/Monocyte Chemoattractant Protein-1 regulates inflammatory responses critical to healing myocardial infarcts. Circ Res. 2005; 96:881-889. [PubMed: 15774854]

62. Hilgendorf I, Gerhardt LM, Tan TC, Winter C, Holderried TA, Chousterman BG, Iwamoto Y, Liao R, Zirlik A, Scherer-Crosbie M, et al. Ly-6Chigh monocytes depend on Nr4a1 to balance both inflammatory and reparative phases in the infarcted myocardium. Circ Res. 2014; 114:1611-1622. [PubMed: 24625784]

63. Courties G, Heidt T, Sebas M, Iwamoto Y, Jeon D, Truelove J, Tricot B, Wojtkiewicz G, Dutta P, Sager HB, et al. In vivo silencing of the transcription factor IRF5 reprograms the macrophage phenotype and improves infarct healing. J Am Coll Cardiol. 2014; 63:1556-1566. [PubMed: 24361318]

64. Korf-Klingebiel M, Reboll MR, Klede S, Brod T, Pich A, Polten F, Napp LC, Bauersachs J, Ganser A, Brinkmann E, et al. Myeloid-derived growth factor (C19orf10) mediates cardiac repair following myocardial infarction. Nat Med. 2015; 21:140-149. [PubMed: 25581518]

65. Epelman S, Liu PP, Mann DL. Role of innate and adaptive immune mechanisms in cardiac injury and repair. Nat Rev Immunol. 2015; 15:117-129. [PubMed: 25614321]

66. Lorchner H, Poling J, Gajawada P, Hou Y, Polyakova V, Kostin S, Adrian-Segarra JM, Boettger T, Wietelmann A, Warnecke H, et al. Myocardial healing requires Reg3beta-dependent accumulation of macrophages in the ischemic heart. Nat Med. 2015; 21:353-362. [PubMed: 25751817]

67. Cheng SC, Quintin J, Cramer RA, Shepardson KM, Saeed S, Kumar V, Giamarellos-Bourboulis EJ, Martens JH, Rao NA, Aghajanirefah A, et al. mTOR- and HIF-1alpha-mediated aerobic glycolysis as metabolic basis for trained immunity. Science. 2014; 345:1250684. [PubMed: 25258083]

68. Netea MG, Quintin J, van der Meer JW. Trained immunity: a memory for innate host defense. Cell Host Microbe. 2011; 9:355-361. [PubMed: 21575907]

69. Saeed S, Quintin J, Kerstens HH, Rao NA, Aghajanirefah A, Matarese F, Cheng SC, Ratter J, Berentsen K, van der Ent MA, et al. Epigenetic programming of monocyte-to-macrophage differentiation and trained innate immunity. Science. 2014; 345:1251086. [PubMed: 25258085]

70. Moore KJ, Tabas I. Macrophages in the pathogenesis of atherosclerosis. Cell. 2011; 145:341-355. [PubMed: 21529710]

71. Moore KJ, Sheedy FJ, Fisher EA. Macrophages in atherosclerosis: a dynamic balance. Nat Rev Immunol. 2013; 13:709-721. [PubMed: 23995626]

72. Tall AR, Yvan-Charvet L. Cholesterol, inflammation and innate immunity. Nat Rev Immunol. 2015; 15:104-116. [PubMed: 25614320]

73. Libby P, Lichtman AH, Hansson GK. Immune effector mechanisms implicated in atherosclerosis: from mice to humans. Immunity. 2013; 38:1092-1104. [PubMed: 23809160]

74. Libby P. Inflammation in atherosclerosis. Nature. 2002; 420:868-874. [PubMed: 12490960]

75. Swirski FK, Libby P, Aikawa E, Alcaide P, Luscinskas FW, Weissleder R, Pittet MJ. Ly-6Chi monocytes dominate hypercholesterolemia-associated monocytosis and give rise to macrophages in atheromata. J Clin Invest. 2007; 117:195-205. [PubMed: 17200719]

76. Tacke F, Alvarez D, Kaplan TJ, Jakubzick C, Spanbroek R, Llodra J, Garin A, Liu J, Mack M, van Rooijen N, et al. Monocyte subsets differentially employ CCR2, CCR5, and CX3CR1 to accumulate within atherosclerotic plaques. J Clin Invest. 2007; 117:185-194. [PubMed: 17200718]

77. Robbins CS, Hilgendorf I, Weber GF, Theurl I, Iwamoto Y, Figueiredo JL, Gorbatov R, Sukhova GK, Gerhardt LM, Smyth D, et al. Local proliferation dominates lesional macrophage accumulation in atherosclerosis. Nat Med. 2013; 19:1166-1172. [PubMed: 23933982]

78. Tabas I. Macrophage death and defective inflammation resolution in atherosclerosis. Nat Rev Immunol. 2010; 10:36-46. [PubMed: 19960040]

79. van Gils JM, Derby MC, Fernandes LR, Ramkhelawon B, Ray TD, Rayner KJ, Parathath S, Distel E, Feig JL, Alvarez-Leite JI, et al. The neuroimmune guidance cue netrin-1 promotes atherosclerosis by inhibiting the emigration of macrophages from plaques. Nat Immunol. 2012; 13:136-143. [PubMed: 22231519] 
80. Jenkins SJ, Ruckerl D, Cook PC, Jones LH, Finkelman FD, van Rooijen N, MacDonald AS, Allen JE. Local macrophage proliferation, rather than recruitment from the blood, is a signature of TH2 inflammation. Science. 2011; 332:1284-1288. [PubMed: 21566158]

81. Swirski FK, Pittet MJ, Kircher MF, Aikawa E, Jaffer FA, Libby P, Weissleder R. Monocyte accumulation in mouse atherogenesis is progressive and proportional to extent of disease. Proc Natl Acad Sci U S A. 2006; 103:10340-10345. [PubMed: 16801531]

82. Jakubzick C, Gautier EL, Gibbings SL, Sojka DK, Schlitzer A, Johnson TE, Ivanov S, Duan Q, Bala S, Condon T, et al. Minimal differentiation of classical monocytes as they survey steady-state tissues and transport antigen to lymph nodes. Immunity. 2013; 39:599-610. [PubMed: 24012416]

83. Swirski FK, Nahrendorf M, Etzrodt M, Wildgruber M, Cortez-Retamozo V, Panizzi P, Figueiredo JL, Kohler RH, Chudnovskiy A, Waterman P, et al. Identification of splenic reservoir monocytes and their deployment to inflammatory sites. Science. 2009; 325:612-616. [PubMed: 19644120]

84. Colom B, Bodkin JV, Beyrau M, Woodfin A, Ody C, Rourke C, Chavakis T, Brohi K, Imhof BA, Nourshargh S. Leukotriene B4-Neutrophil Elastase Axis Drives Neutrophil Reverse Transendothelial Cell Migration In Vivo. Immunity. 2015; 42:1075-1086. [PubMed: 26047922]

85. Nourshargh S, Alon R. Leukocyte migration into inflamed tissues. Immunity. 2014; 41:694-707. [PubMed: 25517612]

86. Murray PJ, Wynn TA. Protective and pathogenic functions of macrophage subsets. Nat Rev Immunol. 2011; 11:723-737. [PubMed: 21997792]

87. Avraham-Davidi I, Yona S, Grunewald M, Landsman L, Cochain C, Silvestre JS, Mizrahi H, Faroja M, Strauss-Ayali D, Mack M, et al. On-site education of VEGF-recruited monocytes improves their performance as angiogenic and accessory cells. J Exp Med. 2013; 210:2611-2625. [PubMed: 24166715] 


\section{Trends Box}

- Cardiac and arterial macrophages first seed their respective tissues during embryogenesis prior to the establishment of definitive hematopoiesis.

- The brain is seeded by yolk sac macrophages that remain in the organ into adulthood. In other tissues, subsequent waves of colonization occur that rely on fetal liver monocytes and, after birth, bone marrow-derived monocytes. The relative contributions of tissue-derived vs. monocyte-derived macrophages is organ-specific and may be age-dependent.

- In the steady state adult aorta, macrophages reside predominantly in the adventitia. These macrophages derive from a brief post-birth monocyte colonization that replaces an earlier embryonic pool.

- Macrophages reside throughout the heart in steady state and are interspersed between cardiomyocytes. Most cardiac macrophages are embryonically-derived, though it has been argued that monocyte-derived macrophages colonize the organ and replace tissue-resident cells progressively throughout life.

- In myocardial infarction and atherosclerosis, bone marrow and spleen-derived monocytes infiltrate the myocardium and intima and give rise to macrophages. It is unknown whether these cells integrate with the resident pool. 


\section{Outstanding Questions Box}

- Does macrophage ontogeny dictate function? Macrophages derive from different sources, but we do not yet know whether their differential generation influences their function. This question can be addressed with lineage tracing studies coupled with functional assessment.

- What are the functions of tissue-resident macrophages beyond those classically described (phagocytosis, inflammation, wound healing and fibrosis)? While we know that macrophages are exquisite eaters, there is also evidence that they pursue functions specific to the organs they inhabit. Cardiovascular macrophage function should be investigated in this context.

- Are tissue-derived macrophages capable of proliferation throughout life, or do they rely on currently unknown progenitors residing in the adult? Tissue-resident macrophages can live for months but eventually are replaced. They may be replaced either by self-renewal of mature macrophages or by yetunidentified tissue progenitors. 


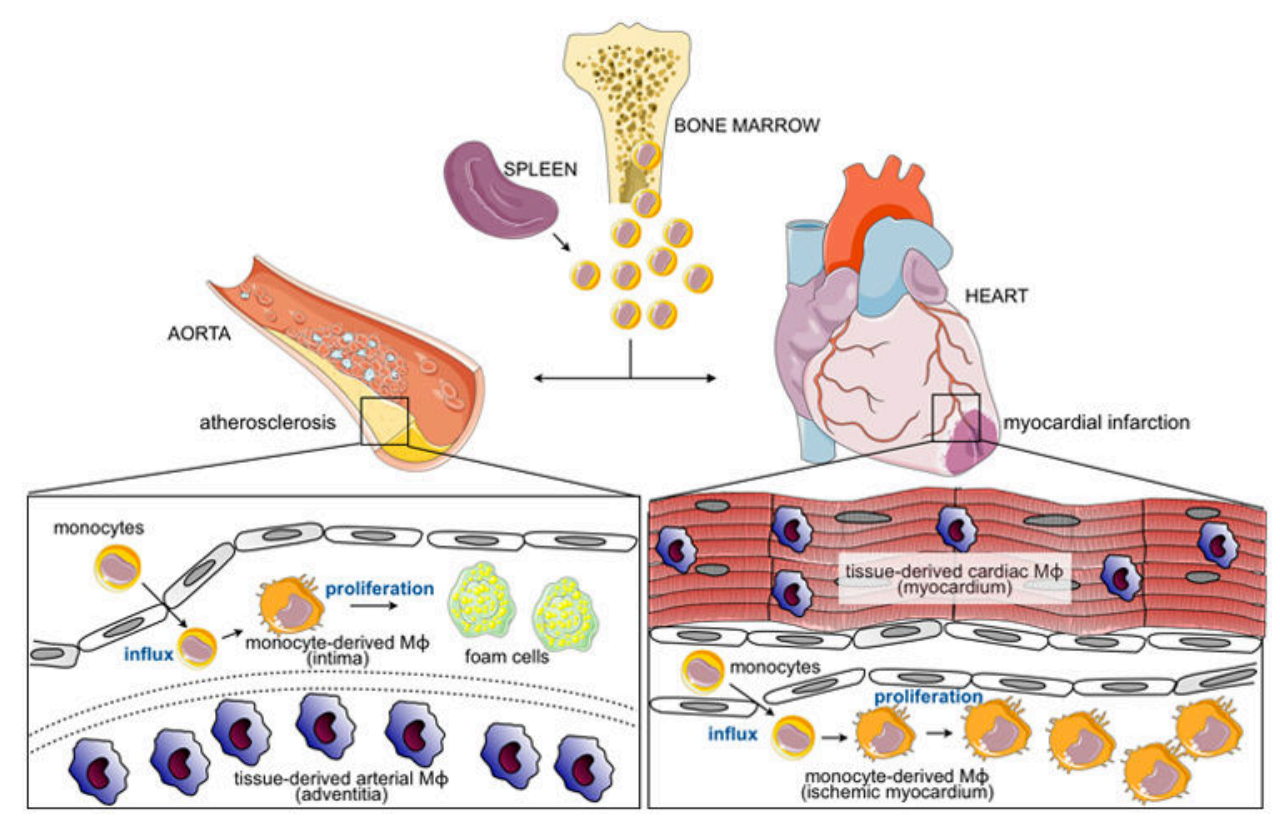

Figure 1.

Arterial and cardiac macrophages in disease and injury. During atherosclerosis or myocardial infarction, hematopoietic sites (bone marrow and to a lesser extent spleen) supply monocytes that infiltrate the aorta and ischemic myocardium, respectively. On influx, monocytes differentiate to macrophages, which can then proliferate. Both sites also contain populations of macrophages that have seeded the tissues during embryogenesis or just after birth. These tissue- derived macrophages self-renew through proliferation. Functions of tissue-derived vs. monocyte-derived macrophages in steady state and inflammation are discussed in text. 